\title{
OM MUSEER OCH UTSTÄLLNINGSSPRÅK
}

Per-Uno Agren

Museet är ett av de otaliga uttrycken for människans strävan efter att ge mening åt omvärldens virrvarr, att bearbeta och söka efter svaren på existentiella frågor - om det individuella medvetandets gàtfulla, tidsbundna ljusglimt mellan två tidlösa mörker, om människolivets ekologiska villkor, om spänningen mellan rationellt och irrationellt i jagets sambälleliga vara, om värdens och värderingars obeständighet.

\section{1 .}

Museets egenart ligger i att det söker sin förståelse, bedriver sitt meningsbyggande i ett idogt studium av det förflutnas materiella spår, i sorteringen, tolkningen och sammanställningen av ting och bilder. Därigenom liknar museet kriminalromanen - dock har det förvisso knappast handlat om brottslighetsaspekten av kulturutvecklingen, utan om den rituella framvisningen av människoandens yppersta prestationer. De erbjuds ögats ställföreträdande beröring som eftersträvansvärda, inspirerande föredömen i förvissningen om att betraktaren mera direkt än genom ord $\mathrm{i}$ «de sammanflätade biografierna av människor och ting»' ${ }^{1}$ kan förnimma, uppleva, andra människors erfarenheter inskrivna $\mathrm{i}$ en annan kultur eller $\mathrm{i}$ en annan tid - deras drömmar och visioner i de efterlämnade kvarblivande materiella resultaten av deras handlingar. "Gjenstanden er fortidens utstrakte hand til oss ... den er en genuin formidler av visuell,

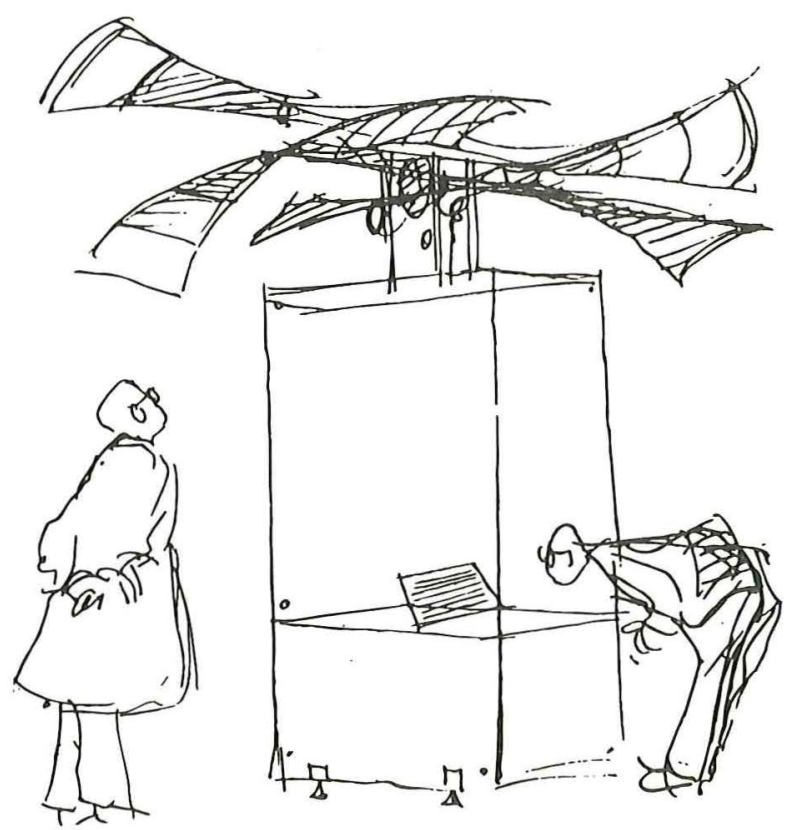

taktil og fölelsesmessig oplevelse». ${ }^{2}$

Den kritiska punkten i musealiseringens meningsbyggande ligger i processens båda beröringsytor mot omvärlden - $\mathrm{i}$ insam- 


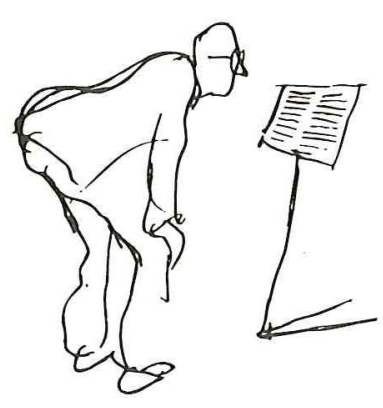

lingen, där urvalet görs, där bruksting transformeras till kunskaps- och upplevelseting och i utställningens framvisning av dem. En spänning uppstår då ofta mellan verklighetsbeskrivningens vetenskapliga ambitioner och den estetiska karaktären i det visuella arrangemang som erbjuds betraktaren. Här konfronteras likaså ofta helt skilda förståelseformer - utställarens och betraktarens.

2.

Utställaren, som vant hanterar utställningskommunikationens konventioner bland skärmar, montrar, podier, visualiseringar och texter, utgår oreflekterat från den självklara relevansen i de förståelseformer som där tillämpas, medan betraktaren normalt förefaller hämta sin förståelse, göra sin tolkning, utifrån en personlig referensram i en riktning som för avsändaren/utställaren ter sig irrelevant eller tillfällig, men där det viktiga är att söka bekräftelse och igenkännande. Illusionen, 'the curatorial fallacy', ligger i att det är skilda förståelseformer som av utställare och betraktare projiceras på det gemensamma - utställningen. Inför utställningsmontern ser båda "sin eigen refleks i gla- set». ${ }^{4}$ Förmodligen därför att utställaren är benägen att förlägga meningen till utställningstexten, medan betraktaren är inriktad på det visuella, där teckenkaraktärens innebörder har stor spännvidd.

Det gemensamma mellan omvärld och museets utställning är realismen. Båda erbjuder igenkännliga ting att se, tolka och förstå. Det skiljaktiga är omvärldens levande, kaotiska virrvarr av ting med sitt nät av vardagliga samband och museets tingen pålagda ordning, ett struktur- eller modellskapande som är intellektets förståelseformer. Båda byggda på underförstådda frågor och erfarenheter, som det är nödvändigt för utställaren att känna för att kunna kommunicera med betraktaren. En avgörande fråga är följaktligen förhållandet mellan åskådarens kontext, den yttre verkligheten, där de referensramar byggts upp som tillämpas under det korta museibesöket och museets inre verklighet, utställarens dagliga kontext, där brottstycken från yttervärlden hämtas in och rutinmässigt görs till byggstenar i en konstruerad verklighet, utställningen som vetenskaplig artefakt, byggd på principer vars exklusiva karaktär utställaren lätt glömmer bort. I konfrontationen med den snabbt passerande besökaren konstitueras tolkningsfältet. Vi ska se hur skilda raster lagts över omvärldens mångfald för att göra bestämda ordningar synliga och hur konventioner för dessa meningars förmedling kodifierats i några vanliga utställningsspråk. ${ }^{5}$

3.

I den kontextuella utställningen visas tingen i en återskapad omgivning, realistisk, men samtidigt overklig. För de kulturhis- 
toriska museernas del blev typen särskilt betydelsefull i den utformning som Artur Hazelius gav den. Först i de tidiga utställningarna i Skandinavisk etnografisk samling som öppnade 1873 vid Drottninggatan i Stockholm, senare i världsutställningen 1878 i Paris. Där fick Bernhard Olsen se hans dräkttablåer, vilket blev en av inspirationskällorna vid inrättandet av Dansk folkemuseum följande år. ${ }^{6}$ Påverkad av det nationalromantiska düsseldorfmåleriet och tidens mycket uppskattade tableaux vivants byggde Hazelius - på jakt efter det förflutnas själ - interiörscener med dockor: det gällde inte bara att återskapa autentiska interiörer utan också att med dockornas gruppering uttrycka stämningar och sinnestillstånd knutna till bestämda situationer. ${ }^{7}$ Den kontextuella utställningsformen möter också i de naturhistoriska museernas dioramor, där Gustaf Koltoffs Biologiska museum på Djurgården i Stockholm, öppnat 1893, med 'Nordens djurvärld sedd i naturen' var ett betydelsefullt initiativ. Utställningsformen anses där snarast återgå på 1800-talets panorama-tradition och kom senare under 1900-talets första decennium att fullt utvecklas i en rad nordamerikanska naturmuseer. ${ }^{8}$ Till utställningstypen måste också räknas de konst- och kulturhistoriska museernas stilrum, som hade blivit mycket vanliga i konstmuseerna vid sekelskiftet 1900 och hade en inflytelserik förespråkare i Wilhelm von Bode, ansvarig för Kaiser Friedrich-museets uppställning på Museumsinsel i Berlin 1904.'

I den isolerande utställningen är det estetiska budskapet i ting och bilder det centrala. De ska ses som unika objekt med ett direkt ordlöst budskap till betraktaren. Här möter ett utställningsspråk som bör- jade uppträda mot slutet av 1800-talet särskilt i konst- och konstslöjdsmuseernas utställningar och bestämdes av den alltmer romantiska syn på konstnärspersonligheten som då utvecklats. Den blev de känsliga esteternas reaktion mot de fullhängda väggar som möter $\mathrm{i}$ bilder av tidigare utställningar och bostadsinteriörer. ${ }^{10}$

I den systematiska utställningen ordnas ting och bilder i serier för att belysa en kronologisk eller taxonomisk, alltså en vetenskaplig/teoretisk ordning. Den är följaktligen forskarens favoriserade utställningsspråk som fick sitt genombrott under upplysningstidens systematiska studium av omvärlden och encyklopediska ambition. I Sverige är Carl von Linné naturligtvis den sorterande systematikens klart lysande företrädare. Detta kom senare att starkt påverkas av utvecklingsläran och har blivit ett av de starkast kvardröjande utställningsspråken. ${ }^{11} \quad$ Etiketterna med klassifikatoriska definitioner som relaterar ett konkret verklighetsinnehåll till en abstrakt begreppsvärld införs som utställningens viktiga meningsgivande undertext. $^{12}$

I den analytiska utställningen riktas intresset mot det enskilda tinget särskilt som uttryck för människans teknologiska bemästrande av omvärlden. Människans närmaste livsrum står i centrum. För att belysa tillverkning och användning utnyttjas grafiskt material - ritningar, teckningar, fotografier, bildserier, diagram, senare rörliga bilder (och ljud) - för att med en alltmer komplex visualisering förmedla kunskap. 'Handens skala' är viktig. ${ }^{13}$

I den berättande utställningen är människan (individer, grupper, samhällen) det centrala. Den kombinerar gärna kontext och analys, söker med texter med samma 
PER-UNO $\AA$ GREN

42 autenticitet som tingen en hermeneutisk förståelse av kulturhistorien genom att berätta om människors livsöden. Med denna berättarteknik kopplas den konkreta individuella tiden som identifikationsgrund till den abstrakta kronologiska tiden.

I den metarealistiska utställningen ställs verklighetens ting som fragment eller citat samman i nya kombinationer för att stimulera fantasin, suggerera tankar, antyda idéer. Utställningsspråket erbjuder 'ting för tanken'; i stället för gängse auktoritativa påståenden om världen framläggs tvivel, debatt, kritik. I stället för bekräftelse: gränsöverskridande. ${ }^{14}$

De flesta faktiskt existerande museiutställningarna utgör blandningar, kombinationer av de här renodlade fem typerna. Utställningar av olika ålder glömmer sig kvar i museerna som spår och avlagringar av förbrukade förståelseformer, står där

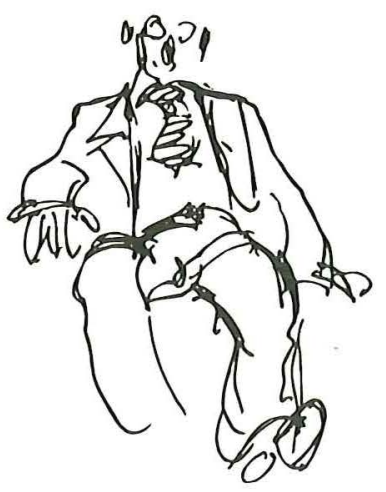

oförmedlat intill varandra som minnen av svar på inte längre aktuella frågor, svar som provisoriskt en kort tid stillat tankens oro. De blir speglingar av en museihistoria som möter tre olika publiker - den kunskapssökande (forskarna, de i utställningsspråken bevandrade), den förståelsesökande, den underhållningssökande,'promenadseende', publiken. ${ }^{15}$

4.

Den komplexitet som varje historisk situation uppvisar med dess samtidigt existerande motstridigheter - mot rigida konservativa mönster frambrytande frigörande rörelser, som i sin tur är dömda att bli etablerade och återhållande - en process ständigt pådriven av nya media för kulturell kommunikation och påverkan. Denna komplexitet ställer nya frågor och medför att de gamla svar som utställningarna konstruerades för att ge, blir överspelade och de gamla undertexternas etiketter hänger som kvarnstenar omkring tingen. Att tingen med sin förblivande fakticitet skulle ge ett slutgiltigt svar på historiska frågor är en förledande och bedräglig föreställning hos många antikvarier, en illusion som framträder särskilt tydligt i uttrycket 'permanent utställning'. Bara som delar av en tidsbetingad kulturell förståelse har de provisorisk mening. Jugoslaven Ivo Maroevic har uttryckt det så att museerna hanterar en särskild klass av data, 'artefakter' (musealia) med en hård materiell kärna omgiven av ett moln av instabila, flyktiga, socialt tillagda betydelser beroende av stundens tolkning. ${ }^{16}$ Alla utställningar är provisorier.

Utställningen erbjuder - för att parafrasera Ricoeur - en skapande referens till 


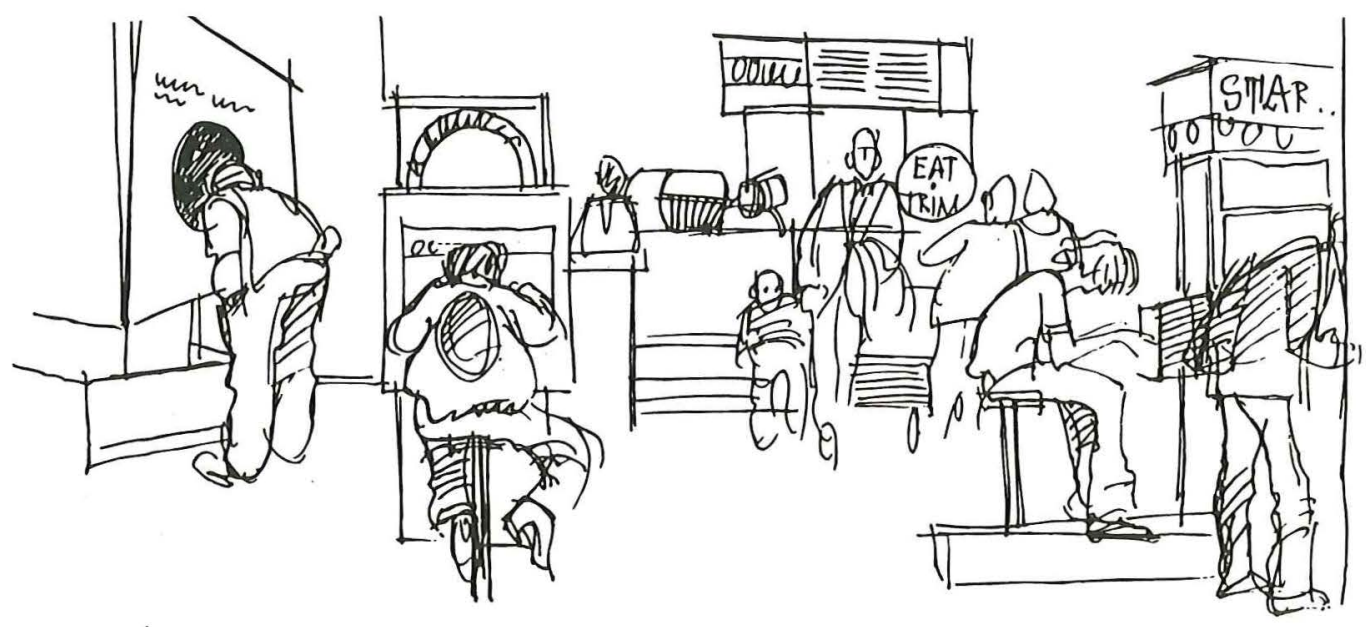

verkligheten, dvs inte till den fysiska verkligheten utan till en betydelsevärld, vars meningar hela tiden nyskapas hos mottagaren/betraktaren i kommunikativa relationer. Sedd på detta sätt är utställningsverksamheten en fortgående humanistisk bearbetning av den kulturella situationen. Och kanske är det, som Ingela Lind en gång uttryckt det, så att det $\mathrm{i}$ en levande kultur alltid någonstans måste finnas en identitetskris, en osäkerhet om rådande tolkningars giltighet, en öppenhet för verklighetens motsägelser, ett ifrågasättande, ett prövande av alternativ. Inte minst i det schizofrena samhälle som samtidigt bygger institutioner för forskning och vägrar att tillämpa de vunna insikterna. Utställningens uppgift, när den är byggd på en aktiv förvaltning av samhällets minne borde vara att belysa den historiska komplexiteten, lyfta fram de bortglömda alternativen, 'kontrafakterna'. H M Enzensbergers ofta citerade sats att museet som samhällets minne inte till sitt väsen skall vara konsekration utan utmaning, äger aktuell tillämpning. "Museet», skriver han,

anses i allmänhet som en sevärdhet, inte en plats för arbete. Riktigare vore att tänka sig museerna som annex till verkstäder, ty de ska inte mumifiera det förgångna, utan göra det användbart, inte undanhålla det en kritisk granskning, utan ständigt utsätta det för en sådan. Därav följer att det aldrig kan slutgiltigt ordnas. Det är inget mausoleum, utan en plats för ständig förändring. Endast när dess anordning svarar på nuets behov kan det anses fylla sin uppgift. ${ }^{17}$

Samma uppfattning har av Antonio Tapiès formulerats så här:

Den estetiska bildningens tillämpningsområde framträder först i det verkliga livet. Ett av de viktigaste är omvärlden, livskvaliteten. Estetisk fostran omfattar ju allt : skyddet av en naturlig livsmiljö, kampen mot miljöförstöring, mot det dödliga hotet från en profitinriktad samhällsplanering och mot den kommersiella reklam som oavbrutet attackerar oss. Problemet är mångskiktat, liksom att de olika stadierna i denna estetiska alfabetisering rymmer 
PER-UnO $\AA$ gren

44 många delproblem. De sträcker sig från en estetisk grundskolepedagogik till en total nyordning av museerna. Inför slutenheten i det reservat där den $s$ $\mathrm{k}$ kulturen äger rum, måste vi inse att de konstnärliga och kulturella problemen inte kan angripas abstrakt, utan att de bara kan lösas om vi samtidigt kan lösa de därmed förbundna pedagogiska svårigheterna. Och är inte kraven på kulturens frigörelse också en del av ett omfattande politiskt problem? Låt oss alltså ge oss politiken i våld!!s

Svaren på det spörjande jagets frågor blir till sist otillfredsställande och futila. Med ett skapande språk, visuellt och verbalt, söker människan förstå och bemästra villkoren i en motsägelsefylld verklighet och vänder därmed hela tiden vår uppmärksamhet åt nya håll; hoppet tänds på nytt och på nytt om att vi ska hitta 'den fråga på vilken människolivet utgör svaret'. ${ }^{19}$

\section{SUMMARY}

\section{On the visual languages of exhibitions}

The paper, which was originally presented at the Holstebro meeting in 1992, reflects on the visual languages which are common in the exhibitions of cultural history museums.

A museum is one of the innumerable expressions of the human urge to assign meaning to the chaos of the surrounding world. Its peculiar nature is to study, order and interpret the scattered material remains of the human past which may be regarded as 'the extended hand of the past, a genuine conveyor of the visual, tactile and emotional experiences of human beings who lived before us'. One basic problem of museum communication is the different ways of perceiving and understanding on the part of the curator and the visitor, the gap bet- ween the intended meaning of the curator and the received meaning formed in the mind of the visitor.

The exhibitor finds the traditional classification and arrangement in the institution self-evident, but the visitor who perceives and interprets according to his personal frame of references has difficulties in adjusting to the scholarly ideas expressed both visually and verbally in the exhibition. To overcome 'the curatorial fallacy' it is necessary to become aware of the conditions of the communication process in an exhibition hall.

Over time the different ways of making sense of the objects have resulted in distinctly different visual languages.

In the contextural exhibition objects are inserted in their, normally reconstructed, context in order to make their original meaning easier to understand. In Sweden this method was introduced by Artur Hazelius, the famous founder of Nordiska museet and Skansen in Stockholm. He first applied it in 1873 and it has had a far-reaching and lasting influence on the presentation of collections in museums of cultural history. It is akin to the 'period rooms' in museums of art and to the dioramas in museums of natural history.

The isolating mode of presentation wants to focus the attention of the visitor on the aesthetic properties of single objects and has been favoured by museums of arts and crafts.

In the systematic exhibition the objects are subordinated to a scientific ordering of the world. It became linked to the way of exploring material reality developed by the Enlightenment and its taxonomic and encyclopedic fervour was in Sweden particularly represented by Carl von Linné. Later it was strongly influenced by evolutionary ideas and has been one of the most common presentational methods in museums.

The analytic exhibition has developed as an expression of the functional study of cultures, where the objects are seen as integrated into ecological, economic and social patterns. It uses a combination 
of media to illustrate these aspects of material objects.

The story-telling exhibition tries to revive the human destinies linked to the objects and thus to stimulate the empathy of the visitor. It uses a multitude of supportive media to bridge the gap of understanding between life in the past and living in the present.

Out of a wish to use material objects to convey more abstract ideas and concepts, the metarealistic exhibition was born. In it objects are combined in unexpected ways to express questions, doubts and uncertainties so as to arouse intellectual curiosity and reflection in the minds of the visitors. It has grown very much out of a dissatisfaction with the often self-sufficient authoritative statements in museum exhibitions.

Most of these exhibition types can be discerned as historical layers in big museums or they meet in various combinations.

The paper ends by referring to the necessity of making both curators and visitors aware of the fact that every exhibiton is a construction, a provisional statement about history, reality and the human condition.

\section{NOTER}

* Texten utgör en bearbetad version av en föreläsning som hölls i Holstebro 6 sept 1992.

1. Uttrycket är Torsten Hägerstrands. Flera av texterna i samlingen Om tidens vidd och tingens ordning (1991) kretsar kring detta tema. För museologisk eftertanke är Hägerstrand en utomordentligt inspirerande författare.

2. Formuleringen är Inger Lise Christies i By og Bygd xxxii, s 189. Tankegången utvecklas utförligt av T. J. Schlereth i den introducerande uppsatsen "Material Culture and Cultural Research" $\mathrm{i}$ den av honom utgivna Material Culture Studies in America (1982).

3. 'Den antikvariska villfarelsen' analyseras skickligt av Charles Saumarez Smith i essän «Museums, artefacts and meanings» i Peter Vergo (ed), The New Museology (1989).

4. Frasen står som rubrik på Anders Johansens (kritiska) artikel om arkeologiska museiutställningar i Museumsnytt 1991/3-4.

5. Termen utställningsspråk användes av Göran Carlsson och mig som titel på en bok 1983. Den förefaller sedan ha kommit att få viss spridning. Helt lyckad är den kanske inte; språk associerar ofrånkomligen till verbal kommunikation och själva poängen med utställningen är ju den visuella kommunikationen.

6. Se Holger Rasmussen i Nordisk Museologi 1993/2, s. 34f, och Bjarne Stoklunds grundliga utredning «International Exhibitions and the New Museum Concept in the Latter Half of the Nineteenth Century» i Ethnologia Scandinavia, Vol. 23, 1993.

7. Jämför Eva Perssons reflexion i Utställningsform (1994), s. 39.

8. Se Allan Ellenius-Karen Wonders, "Verklig eller blott målad?», Tvärsnitt 1991/1-2, s. 21-29.

9. Den märklige museimannen Alexander Dorner, biograferad av S. Cauman i The living Museum (1958), fullföljde Bodes tankegångar in i sin samtid med det berömda 'abstrakta kabinettet' i Hannover 1925. Det togs bort under nazisttiden, men har numera rekonstruerats.

10. Se t ex Richard Berghs utomordentligt läsvärda uppsats «Konstmuseet som skönhetsvärld» i Ord och Bild 1915, s. 209-215.

11. Diskuteras utförligt i katalogen till utställningen Museum Europa (1993) - se Nordisk Museologi 1993/2 och 1994/1. Se även Walter Grasskamps uppsats "Museum og encyklopedi» i Den jyske historiker $\mathrm{nr} 64$ (1993).

12. Se Linnés Naturaliesamlingars ändamål och nytta (1754). Om konfrontationen mellan de hazelianska och systematiska utställningsspråken om 
PER-UNO $\AA$ GREN

46 herraväldet som museal kommunikationsform har Ernst Folke Lindberg publicerat den viktiga undersökningen "Gunnar Hazelius och Nordiska museets installationsfråga» $\mathrm{i} R I G 1957$.

13. Se Albert Eskeröd, «Museum - medium - människa", i Fataburen 1967.

14. Eva Persson företräder detta sökande efter ett visuellt språk som närmar utställningen till den konstnärliga installationen. Hennes bok Utställningsform (1994) handlar om detta sökande efter nya möjliga uttryck i utställningsgestaltningen. Jacques Hainard i Neuchâtel, Marie Louise von Plessen och Peter Greenaway, båda verksamma i hela Europa är uppmärksammade samtida företrädare för detta utställningsspråk. von Plessen utvecklar filosofin i sitt utställningsspråk i «Af kaerlighed til tingene» i Den jyske historiker 64 (jfr not 11).

15. Uttrycket är Sigurd Wallins i «Det kulturhistoriska museiföremålet» i Fataburen 1955. Jämför Frans Schoutens 'skyltfönstertittande' museibesökare i "Kartans paradox» (i Svenska Museer 1987/5-6) och termen 'window-shopping' som Heiner Treinen använder för att karakterisera ett vanligt besökarbeteende i museer.

16. Ivo Maroevic, Museology as a part of information sciences. 'Paper' presenterat vid ICOFOM-möte i London 1983.

17. H.M.Enzensbergers Museum der modernen Poesie utkom 1960. Det citerade utdraget ur förordets avsnitt 'Möglicher Nutzens eines Museums' är översatt efter en fickboksupplaga 1966.

18. Antonio Tapiès, "Die Aufgabe der Kunst und die Aufgabe der Gesellschaft.» Ursprungligen tryckt i La Vanguardia 1973. Utdraget översatt från en tysk version tillgänglig i samlingen Kunst contra Ästhetik (1983).

19. Willy Kyrklund, Mästaren Ma (1953).

De inströdda teckningarna föreställande utställningsbesökare är utförda av Göran Carlsson och hämtade ur boken Utställningsspråk.

Per-Uno Agren är fd högskolelektor i museologi vid Umea universitet. Han arbetade åren 1953-83 vid Västerbottens museum, Umea.

Adr: Mariehemsvägen 11G, S-906 54 Umeå.

Fax +46-90-139852.

\section{Apropå -}

Av alla de händelser som ägt rum i det forflutna är det bara ytterst fä som tematiseras av historikerna och som därigenom blir en del av "det gemensamma kulturarvet», och de tolkas gärna inom ramen av ett nationsbygge. Senare skrev Immanuel Wallersten i en tillspetsad formulering att historien inte skapas av det forflutna utan av samtidens önskningar och behov. (Thomas Hylland Eriksen i SvD 5/1/95)

Das Museumswesen hat der Tendenz zur Unanschaulichkeit wissenschaftsbezogener Darlegungen widerstanden; historische Objekte werden in ihrer Ganzheit angeboten und nicht in ihrer von Historikern hervorgehobenen speziellen Bedeutung allein. (Heiner Treinen, 1994)

Tidsformerna blandar sina kärl; då och nu klarnar i varandra. Det är konsten och samtidigt det okomplicerade livet. (Björn Ranelid i DN 8/1/95) 